\title{
Are Tent Cities an Illusion of Success? Clients' Perceptions of Neoliberalism Strategies
}

\author{
Francisco J. Alatorre \\ Department of Criminal Justice, New Mexico State University, Las Cruces, NM, USA \\ Email: falatorr@nmsu.edu
}

How to cite this paper: Alatorre, F.J. (2016) Are Tent Cities an Illusion of Success? Clients' Perceptions of Neoliberalism Strategies. Open Journal of Social Sciences, 4, 123-132.

http://dx.doi.org/10.4236/jss.2016.411010

Received: September 28, 2016

Accepted: November 22, 2016

Published: November 25, 2016

Copyright (C) 2016 by author and Scientific Research Publishing Inc. This work is licensed under the Creative Commons Attribution International License (CC BY 4.0)

http://creativecommons.org/licenses/by/4.0/

\begin{abstract}
The term, neoliberalism has been used to describe the overarching political and economic framework in which services for the poor living outside institutional life has operated for roughly the past 30 years. This implies a unified intent to "manage the poor" to benefit the larger society, in particular the business sector and the wealthy which are the key actors in society according to neoliberal doctrine. This paper explores and questions the conventional ideology of "managing the poor" and thus inquires further about the identified objectives of such management: whether such programs are intended to help the homeless re-establish themselves or prevent them from impinging on the wealthier classes. This questioning is done by reporting on and analyzing the experiences of twenty homeless people who are currently being "managed" by services provided by the agency Mesilla Valley Community of Hope (MVCH) in Las Cruces, New Mexico. This agency, reflecting Neoliberal doctrines, has created and manages a tent city which provides services for people who are homeless and near homeless. These services include showers, laundry, mail, voice mail, phone, lockers, case management, training programs, and donated goods, including clothing, shoes, hygiene products and household goods. $\mathrm{MVCH}$ also has various housing programs including transitional and permanent housing for people who are homeless. The findings derived from the interviewed participants reveal that "the managed" provide a contrasting view with those who assess neoliberalism practices as only benefiting society.
\end{abstract}

\section{Keywords}

Neoliberalism, Homeless, Tent Cities, Qualitative Methodology, Resiliency, Felons

\section{Introduction}

According to neoliberalism scholars, neoliberalism promotes a "homeless factory" al- 
though its proponents did not intend these negative side effects (Bourgois, 2011) [1]. Furthermore, after President Reagan started implementing neoliberal policies, homelessness came to be treated like a natural disaster; that is, something that was expected to happen. Uprooted people were housed in emergency shelters and tent cities and were "managed" to promote their well-being and re-entry into society (Harvey, 2007) [2]. However, this ideology, as laudable as it seems, tends to view the homeless through a single lens, and therefore molding the homeless into one being. This top-down approach of management does not treat the homeless as individuals (Herring, 2010) [3]. This one-size fits all approach and its failures can be better understood by exploring with the experiences and opinions of various homeless men and women being sheltered and "managed" at MVCH, in Las Cruces, New Mexico.

The term "manage," used here in a positive and very limited, nuanced sense, and reflecting neoliberalism ideology, can be defined as "the interaction between organizations or groups and individuals who obtain services through agencies whose actions aim to achieve a certain end, namely the relief of poverty." Neoliberalism as defined by David Harvey (2007):

Neoliberalism is in the first instance a theory of political economic practices that proposes that human well-being can best be advanced by liberating individual entrepreneurial freedoms and skills within an institutional framework characterized by strong private property rights, free markets and free trade. The role of the state is to create and preserve an institutional framework appropriate to such practices. The state has to guarantee, for example, the quality and integrity of money. It must set up those military, defense, police, and legal structures and functions required to secure private property rights and to guarantee, by force if need be, the proper functioning of markets.

Harvey argues that neoliberalism has become dominant globally in the past 30 years, in significant part because it appeals to "our instincts and intuitions, our values and desires ... political ideals of human dignity and individual freedom as fundamental, as the 'central values of civilization'." However, there has been much criticism of Neoliberalism in regard to its effects on the poor; or the people who have not been "successful" in the market. Bourgois (2011) stated that because of governmental reduction of services to the poor as neoliberal imperatives replaced the government's actions, local agencies have filled this gap by providing soup kitchens, clinics, and shelters. These services have become a major point of contact between the poor and the rest of society. Services are not merely soup lines and showers; services now include medical help and counseling on everything from drug addiction, anger management, to job searching. Two important questions can be asked: do such services exist merely to segregate the poor from the rest of society and forestall public disorder?- some posit that goods and services are offered or withheld, as lures and rewards for "good" behavior. Or, do these services help the poor and the homeless to empower themselves and to foster positive relations with people in other social classes?

The implication of this first question is that "managing the poor" is done not to help the poor, but to prevent them from disrupting business activity and harming the inter- 
ests of the wealthier classes. Herring (2010) describes "spatial management" of the poor, by which homeless people are set up in "tent cities," that, although often subject to raids by the police, primarily serve to separate homeless people from upscale residential areas and shopping malls where homeless people are not wanted. Though not all studies confirm such criticisms, the research set forth here was conducted in the spirit of examining if real-world conditions confirm or deny the idea that managing the poor is less to help them re-establish themselves in society than to prevent them from impinging on the wealthier classes (Lyon-Callo, 1964) [4]. Homeless services management, because it is more available and more willing than the homeless to speak on such issues, has been frequently consulted rather than the homeless themselves. The ideas and opinions of the management are valuable; however, what do the recipients of this management think, believe, and say about these various issues arising from neoliberal doctrines? Thus, the key question of this study: how are these services perceived by the recipients? A related question: should their perceptions be examined and applied to improving key goals and objectives in "managing the poor"? In terms of our study, we explore these ideas by learning how twenty homeless people, both male and female, perceive their status as being homeless, how they regard the goods and services offered as a step toward successfully re-entering society again and if they believe these services can empower them

\section{Literature Review}

This literature review provides a single lens by which to consider the lives and responses of the twenty interviewed participants: is "management" of the poor and homeless compassionate assistance or do they largely operate to keep the homeless under control in the urban environment? Additionally, these articles work on two levels for the purpose of this study. Not only do they provide information about neoliberal strategies being employed at shelters; these articles also reveal the gap in perception that this study attempts to address: we do not hear the voices and perceptions of those in the shelters; rather, we hear the voices of the management, and the voice of those conducting the study.

Stacey Murphy's "Compassionate Strategies of Managing Homelessness: PostRevanchist Geographies in San Francisco," [5] considers how the cities, since federal funding has receded to assist the homeless, have built policies that attempt to balance expansion of the cities with neoliberal theories of assisting poverty. San Francisco, which has always had a large homeless population, created the "Care Not Cash" program which has alleviated punitive measures against the homeless, organized homeless assistance in goods and services, but has not succeeded in terms of the "logic of compassion." The program seems to address the causes of poverty, and in doing so has mobilized space and resources for the housing of the homeless and seeks to empower them through programs and resources to move into jobs. Serious gaps exist in this program; housing is sub-standard; the mentally ill are not given the care they need, and some forms of assistance are hard to access and then are "intolerable in demands;" and choice for the homeless is lacking. Though not condemning the program or neoliberal doctrines, 
Murphy expresses pessimism about its outcomes which as of 2004 had not been assessed.

Zoe Loftus-Farren's "Tent Cities: An Interim Solution to Homelessness and Affordable Housing Shortages in the United States" (2011) [6] considers the phenomenon of tent cities in positive terms, contrasting their positives with agency-created shelters. While acknowledging the serious drawbacks of tent cities, Loftus-Farren argues that tent cities, whether led by their inhabitants, or conducted by agencies and churches, fill a gap in current governmental responses to homelessness, and can grant the right for the homeless to create their own communities, though such arrangements exhibit drawbacks and difficulties associated with informal housing. Tent cities offer a degree of autonomy to their residents, and can avoid or solve problems plaguing shelters, such as lack of accommodation for couples living together, and restrictive schedules and rule-bound agendas. The freedom of movement is prized by tent-cities dwellers as well as the feeling they are conducting their own lives and making their own decisions.

Vincent J. Del Casino and Christine L. Jocoy's "Neoliberal Subjectivities, the 'New' Homelessness and Struggles over Space of/in the City" (2008) [7] makes a point that the terrain of homelessness according to homelessness discourse needs interrogating: one profile for the homeless seems to fit everybody-this is inherently unfair when discussing large groups of people, as well as being used a weapon for managing the homeless. Theoretical beliefs do not translate into action, whether political or compassionate, and unless the "discursive foundations of homeless policy" are deconstructed, equitable programs and services cannot be fairly created or administered.

"Tales of Tent City," by Ben Ehrenreich (2009) [8] describes homeless encampments as a product of growing inequality in housing. Disturbingly, tent cities even have employed living in them because their paychecks can't cover the cost of a roof and food. Ehrenreich also provides an account of how Ontario California dealt with the homeless, by requiring they provide proof they were residents of the city; those who qualified were then placed in an official tent city, with ID cards and a security force. Those who were in the shelter were fed three times a day, left alone, and did not complain much, but the author suggests how the tidy camp more or less kept this population under control and away from other population areas.

“'Weak-Center' Gentrification and the Contradictions of Containment: Deconcentrating Poverty in Downtown Los Angeles” (2010) [9] by Ellen Reese, Geoffrey Deverteueil, and Leann Thach examines how, as gentrification transforms areas of homeless and poverty, there is increasing criminalization of the two conditions and displacement not only of available housing but of services. Neoliberal doctrines provide evidence that the government and local government attempt to manage prime urban areas and assist the homeless yet clearly the homeless remain homeless as they leave the contested areas. These vulnerable populations which had certain survival strategies in an area termed "Skid Row" are now being disposed with a reduction of whatever power they once possessed.

\section{Methodology}

This design used a qualitative sample of twenty homeless people drawn from the agency 
Mesilla Valley Community of Hope in Las Cruces, New Mexico. All the participants were adults out of the twenty participants, the majority was white and only three were Hispanic. Five of the participants were women and no one was a native of Las Cruces, NM. Three of the participants had higher education, the remaining had only high school level of education and two were illiterates. The actual perceptions of the recipients of the agency's services will bear directly on the question of "managing the poor" in terms of their reported perceptions.

The research consisted of twenty open-ended interviews; the research team also attended several group meetings of the residents. The sampling was purposive and not random because our intention was to purposefully select individuals and settings that would allow us to maximize our understanding of the phenomenon (Alatorre, 2012) [10]. Furthermore, the goal for this study was not to obtain a large representative sample and to generalize our findings to a bigger population; rather our goal, in line with Onwuegbuzie and Leech (2007) [11], is more exploratory as we seek to "to obtain insights into a particular social process and practices that prevail within specific location."

The qualitative analysis was conducted via a humanistic methodology by which we assumed a "naturalistic perspective" (Sandstrom, et al., 2003) [12]. This choice of methodology and development of a naturalistic perspective was critical to this study because we sought to understand human conduct in its context. Through naturalistic inquiry we developed two levels of analysis: exploration and inspection (Sandstrom, et al., 2003).

In the first stage, we became familiar with the social world we studied. In this stage, we immersed ourselves in the social world of homeless people by observing and interacting with them at the tent program and also by attending several group meetings in the agency meeting/classroom. This immersion helped us understand how members of this world experience and negotiate life and relationships with each other (Sandstrom et al., 2003). Becoming more sensitive was crucial in order to understand those whom we studied. In the second stage of this qualitative analysis, the researchers conducted a systematic inspection of the substantive data which had been created by interviews.

By these results we highlighted important themes that consistently emerged through the narratives. The raw data were studied for themes and consistent occurrences and/or reactions from the homeless people. The basic narrative pattern was structured in the following sections: a description of the homeless experiences; the reasons and motivations for the homeless to seek assistance; and their reflections on their specific experiences on interactions with other homeless people and management. A description of specific issues and obstacles that they confronted on a daily basis was included (Wengraf, 2001[13], Charmaz, 2001[14], Emerson et al, 1995 [15]). Concluding the analysis are their thoughts about being managed by the staff at MVCH. By these conclusions, the researchers sought to develop generalizations, as described by Wengraf (2001).

\section{Results and Discussion}

All of the interviewed subjects and their stories can be explored to offer insight into 
how people in homeless circumstances perceive being "managed" by a non-profit organization. The interviewed subjects have had varying experiences with homelessness; with some bringing in previous experiences with incarceration. Nearly all the subjects have three qualities in common: they accept a degree of responsibility over their homelessness, and for some, their incarceration. They express appreciation of the agency's efforts to provide services for their upkeep and to prepare them to re-enter society. They also display desire, though in varying degrees, to re-enter society though there is a sense it is on their own terms in that they will allow the agency to assist them, but they are not necessarily docile cogs.

Many of the participants have experiences of incarceration which contributed to their homelessness; these same participants had once lived within conventional social boundaries and rules. All participants stated or suggested that they appreciated living within the social boundaries they knew previous to their homeless state, such as serving in the army, having jobs, being married, and having children. Although domestic abuse, alcohol and drugs were present in their previous circumstances, and contributed to their imprisonments and homelessness, they had a "sense of self" of being in a "normal" community, which supports their announced desire to re-enter society. However, they do not complain unduly about their lives being "managed" by the social agency. Their collective reaction indicates that, although they considered themselves being managed, they regard it as a positive experience; indeed, as a "dynamic integration strategy" that would help them to construct new identities (Valenta, 2009) [16].

Of the male tent city residents in the study, 70\% participants indicate varying degrees of regarding their experiences as being positive. They are similar in that they attended school, even advanced instruction, but also served time in prison, in varying amounts, yet hold themselves responsible for their choices. They accept the services at the agency with varying amounts of enthusiasm, although they claim they understand how the services are to assist them. One participant attended high school, some college, and was in the Marine Corps for eight years, but then did prison time for unspecified reasons. $\mathrm{He}$ claims "anger management issues," and that he has problems adjusting, and tends to take "an anthill and make into a mountain." Although he is not in complete accordance with the rules and regulations of the tent city, and does not approve of the staff, claiming their attitude is "I don't have time," he regards the place as a sanctuary. Since being at $\mathrm{MVCH}$ he can see himself returning to society, though his understanding of success is not clear to the interviewer, but indeed reveals a certain amount of fear of returning to society.

Another participant, who obtained his GED and trained to be a carpenter through Job Corps, also served time in prison, after turning himself in to the police. He states that the homeless shelter "is where I need to be." He appreciates the staff's caring attitude, and that services provided by the agency will help him become successful. The third participant of this group claims some advanced education, but by the early nineties he was in prison, and has since been in a halfway house, and has worked. His homeless status he regards as his own choice, which perhaps is a euphemism for his 
current status being "his fault." His positive feelings even extend to police, whom, he figures, "have a job to do." He does not particularly care for the staff at MVCH, even declaring them "biased," yet he appreciates the services offered. However, he is not sure about his future success after being managed by the agency, and calls the services offered-voice mail, a place to receive mail, food and showers, etc., "an illusion of success." This is an intriguing idea which he did not pursue. Another participant, as the three men above, once lived in fairly conventional circumstances, even to staying at home to take care of the children while his now ex-wife worked as a pharmacist. He too was in trouble with the law, and served fourteen days in jail (one charge was child neglect) and is on probation. He finds the agency to be helpful with food services and in AA counseling. Ironically, he is working, though his income is not enough for him to live on his own.

A female participant will be considered separately because her experiences are not quite parallel with the preceding male participants. She too has received some advanced education, and even attended a trade school, and is homeless because she fairly recently lost a job-by which, she claims, alleging sexual harassment against her employer. She deliberately chose La Mesilla after conducting research on the Internet and traveled by bus to Las Cruces from Kentucky; she intends to return to Michigan. This woman participant seems among the most optimistic and cheerful, declaring she feels safe. The staff is friendly, and her case manager extremely helpful. As do the male participants, she seems to respond well to management, using it as a resource and a guide to find resources that she needs and to make active decisions about her next steps in life.

Another female participant stands in some contrast with this woman resident. Both women seem to have had a fairly conventional kind of home life, with our second woman describing her mother and father as giving her a "privileged" childhood. But whereas the first woman lost her job, the second woman life is marked with incarceration, drug use and broken marriages. After being referred to $\mathrm{MVCH}$, the woman is highly appreciative that everything is free, the staff is great, and that she was taking some control of her life. Neither woman's experiences gives us any insight into how gender and age and other factors contribute to homelessness, but once again reveals that homeless shelter residents who have had good experiences with conventional life seem positive about being managed. Their cooperation with services, technically "management," which range from sincere to superficial appreciation seemingly arise from their positive descriptions of living with socially controlled boundaries in the past, perhaps seeing it as an ideal from which they have fallen.

However, some of them were more passive about management, neither seeing it as a positive nor a negative opportunity. Notably, the one participant in this study who both appreciates and has little sense of being "managed," whether positively or negatively, is an older man who seems to suffer from a degree of psychosis. Although being married and widowed, having a home until at least 2008, and working, this participant seems vague, out of touch, and "practically incapable of reflecting on his past, being barely able to make sense out of anything." This participant seems contented with the agency, 
which he sees as "giving stuff" rather than providing means for the homeless to assume responsibility for themselves.

When reviewing and exploring the participants' experiences and responses, it seems that patterns of incarceration, illness, and inability to return to work indicate a loss of conventional identity which they fully understand and regret its loss, even to accepting a degree of blame, even when their situations, rather than personal decisions, may have created their homeless situation. Several of the participants stated that rather than seeking new meanings in their new state as homeless, they regard their experiences as unfortunate, but yet having a degree of meaning because they accept their experiences as the inevitable result of "messing up." One participant declares that if he thought society owed him anything for being homeless "he got over that real fast." He also calls being homeless as "hard on self-esteem," but believes that the agency's services have helped him re-find his self-esteem. Another participant admitted to using drugs, alcohol, and having "Illicit sexual encounters" and with all of that together, "you're gonna have problems," an extension and explanation of his current homeless state. Another participant, who lost his job and his family by alcohol and a series of violations of the law, admitted that his troubles were "a result of his own actions" and "I created this whole mess by myself." Those who claim that they are the source of their problems also seem willing to accept services in order to "get themselves together." Several participants who are nervous about authority figures such as police officers, also say they respect them, and one even admitted that the police and the local sheriff have their work to accomplish.

Their gestures toward renewed interaction with society can be understood in their claim that many of them keep fighting to attain and maintain sobriety, with one participant stating "I am getting myself together." Another participant made a statement praising Mesilla Valley of Hope as a "wonderful place," and another participant is using the counselling services so she can leave and regain custody of her son, though her success in this seems doubtful. Overall the participants presented an idea that recurred among our subjects - they all accepted responsibility for their problems. Even if their statements have a degree of superficiality in them, such remarks indicate that they know that is a way of rejoining conventional society, and feeling as if they are part of a conventional community.

\section{Conclusions}

Exploring the experiences of our homeless people point to two ideas: that all feel in some degree "helped" by their being "managed" by an agency, and that these feelings seem to come from prior experience with conventional society such as working for a living, supporting a family, and having family relationships, and then running afoul of conventional society by alcoholism, criminal acts, and, having conflicts with various kinds of authority. There seems to be little feeling of getting "rewarded" for good behavior, in the sense that a young child might be rewarded for behavior which has a purpose he does not yet understand other than that the person offering the reward wants 
it - which counters the idea of "lures and rewards" mentioned earlier. Rather, they seemed grateful for the services, or at least they understood that these are services were being afforded to them, while they also understand the possible future rewards of returning to conventional living in mainstream society. Our participants are conscious that there is a reciprocal ideology present in their circumstances; these services are not offered without expectations from the officers. From a theoretical perspective, being "managed" gives the dwellers in this tent city and receivers of services the resources and the "cues" to interact with society, and seem reasonably content to do so.

This is not to say that neoliberal objectives of "managing the poor" are the ideal which government and non-profit organization should seek and attain. The goal should be to help people to end their poverty and homelessness. Moreover, these cases suggest that accepted social values are usually present among those who are screened for the various processes of management. In particular, these values were probably responsible for our participants of coming and staying within the parameters of the agency's housing and offering of services, which indicates how neoliberal doctrines are not merely for segregation of the homeless, but assist in helping the homeless re-establish themselves.

In light of these interviews, an answer finally arises to the question "Do these services exist to segregate the poor from the rest of society and forestall public disorder by providing goods or services that can be withheld as rewards/lures for good behavior?" From the feedback gathered from the participants, it is evident that the natures of the services these clients have received directly challenge the segregation that could occur in neoliberal conditions. Instead of being set aside from the rest of the population, the individuals in the study expressed that their interaction with the agency helped them to deal with their circumstances.

This study is limited in that it reflects the lives of a relatively small amount of people and their experiences with one social agency. Moreover, it could be that these people are fairly unique in the homeless shelter in being willing to talk with interviewers and speak freely of their problems and their positive feelings about the staff and services. It is impossible to generalize to the larger population of the homeless. Nevertheless, the interviews presented in this paper are insightful because the voices of the homeless are being heard, including their opinions about seeking and receiving goods and services from an agency. The neoliberal idea that the rich and powerful manage the poor in order to exclude them, or to make conventional society feel safe from them, is seemingly at variance with their attitudes. They feel assisted, safe, and grateful and their views seem to align with conventional society's conception of what makes a person a valued contributor to its strength and stability.

\section{References}

[1] Bourgois, P. (2011) Lumpen Abuse: The Human Cost of Righteous Neoliberalism. City and Society, 23, 2-12. http://dx.doi.org/10.1111/j.1548-744X.2011.01045.x

[2] Harvey, D. (2007) A Brief History of Neoliberalism. Oxford University Press, Oxford.

[3] Herring, D. (2010) Tent Cities in America: A Pacific Coast Report. A Report for the Na- 
tional Coalition for the Homeless. www.nationalhomeless.org

[4] Lyon-Callo, V. (2004) Inequality, Poverty, and Neoliberal Governance: Activist Ethnography in the Homeless Sheltering Industry. Broadview Press, Peterborough, Ont.; \& Orchard Park, NY.

[5] Murphy, S. (2009) Compassionate Strategies for Managing the Homeless: Post-Revanchist Strategies in San Francisco. Antipode, 41, 305-322. http://dx.doi.org/10.1111/j.1467-8330.2009.00674.x

[6] Loftus-Farren, Z. (2011) Tent Cities: An Interim Solution to Homelessness and Affordable Housing Shortages in the United States. California Law Review, 99, 1037-1082.

[7] Del Cansino, V.J. and Jocoy, C.L. (2008) Neoliberal Subjectivities, the "New" Homelessness, and Struggles over Spaces of/in the City. Antipode, 40, 192-199.

http://dx.doi.org/10.1111/j.1467-8330.2008.00583.x

[8] Ehrenreich, B. (2009) Tales of Tent City: In Boom and in Bust, Homeless Encampments Are a Product of Inequality and Neglect. The Nation. https://www.thenation.com/article/tales-tent-city/

[9] Reese, E. and Deverteuil, G. (2010) Weak-Center' Gentrification and the Contradictions of Containment: Deconcentrating Poverty in Downtown Los Angeles. International Journal of Urban and Regional Research, 2, 310-327. http://dx.doi.org/10.1111/j.1468-2427.2010.00900.x

[10] Alatorre, F. (2012) Social and Political Integration. In: Gans, J., Replogle, E.M., \& Tichenor, D.J., Eds., Debates on US Immigration, SAGE Publications, Thousand Oaks, 416-428.

[11] Onwuegbuzie, A.J. and Leech, N.L. (2007) A Call for Qualitative Power Analysis. Quality \& Quantity, 41, 105-121. http://dx.doi.org/10.1007/s11135-005-1098-1

[12] Sandstrom, K., Martin, D. and Fine, G. (2003) Symbols, Selves and Social Reality. Roxbury Publishing, Los Angeles.

[13] Wengraf, T. (2001) Concepts and Approaches to Depth Interviewing. In Qualitative Research Interviewing. In: Wengraf, T., Ed., Qualitative Research Interviewing, Sage Publications, Ltd., Thousand Oaks, 1-66.

[14] Charmaz, K. (2001) Grounded Theory. In: Emerson, R.M., Ed., Contemporary Field Research, Waveland Press, Inc., Long Grove, 335-352.

[15] Emerson, M.R., Fretz, I.R. and Shaw, L.L. (1995) Writing Ethnographic Field Notes. The University of Chicago Press. Ltd., London. http://dx.doi.org/10.7208/chicago/9780226206851.001.0001

[16] Valenta, M. (2009) Immigrant's Identity Negotiation and Coping with Stigma in Different Relational Frames. Symbolic Interaction, 32, 351-371.

http://dx.doi.org/10.1525/si.2009.32.4.351 
Submit or recommend next manuscript to SCIRP and we will provide best service for you:

Accepting pre-submission inquiries through Email, Facebook, LinkedIn, Twitter, etc. A wide selection of journals (inclusive of 9 subjects, more than 200 journals)

Providing 24-hour high-quality service

User-friendly online submission system

Fair and swift peer-review system

Efficient typesetting and proofreading procedure

Display of the result of downloads and visits, as well as the number of cited articles

Maximum dissemination of your research work

Submit your manuscript at: http://papersubmission.scirp.org/

Orcontact jss@scirp.org 